\title{
UNIVERSITAS AL-AZHAR SEJAK ABAD KE-20
}

\author{
Muhammad Idris \\ Sekolah Tinggi Agama Islam Al-Hikmah Sumatera Utara Medan \\ Email: abuyahya664@gmail.com
}

\begin{abstract}
Abstrak
Al-Azhar dalam perkembangannya, bukan saja sebagai tempat untuk mendalami ilmu agama atau penampungan bagi orang-orang miskin, bahkan al-Azhar juga merupakan tempat pemersatu umat dalam perjuangan membebaskan Mesir dari penjajahan. Keistimewaan al-Azhar, tidak hanya piawai dalam melahirkan ulama-ulama yang berkualitas, akan tetapi ia juga membangun peradaban dunia melalui dua cara, yaitu dengan kepribadian yang dimiliki oleh al-Azhar sendiri, dan melalui lulusanlulusannya yang membawa perubahan terhadap masyarakat dunia.AlAzhar tidak hanya menjadi sejarah, tetapi menyaksikan dan mengukir sejarah dalam keajaiban dunia pendidikan dan peradaban.Dan keberadaan al-Azhar bukti nyata bahwa Islam adalah agama yang peduli terhadap pendidikan, kesehatan, kesenian, serta ilmu pengetahuan umum lainnya.
\end{abstract}

\begin{abstract}
Al-Azhar in its development, not only as a place to study religion or shelter for the poor, even al-Azhar is also a unifying place for the people in the struggle to free Egypt from colonialism. The specialty of al-Azhar is not only skilled in producing quality scholars, but it also builds world civilization in two ways, namely the personality possessed by al-Azhar itself, and through its graduates who bring change to the world community. Al-Azhar not only becomes history, but witnesses and carves history in the wonders of the world of education and civilization. And the existence of al-Azhar is clear evidence that Islam is a religion that cares about education, health, arts, and other general sciences.
\end{abstract}

Kata Kunci: Universitas Al-Azhar, Abad 20. 


\section{Muhammad Idris}

\section{Pendahuluan}

Jami atul-Azhar merupakan suatu lembaga pendidikan yang diawali pembangunan sebuah masjid yang merupakan sebagai sarana pendidikan yang memiliki fungsi yang lebih besar dibanding fungsinya sekarang. Al-Azhar merupakan sarana dakwah yang gunakan oleh Dinasti Fatimiyah sejak satu millennium lebih yang lalu yang mampu menjembatani antara dakwah dan politik demi mengembangkan ajaran Syi`ah, dan Al-Azhar merupakan perguruan Islam tertua di dunia. ${ }^{1}$

Universitas Al-Azhar merupakan hasil dari pengembangan masjid sebagai pendidikan.Pendidikan menghendaki tersedianya tempat, adanya sarana dan prasarana yang memadai dan tempat tinggal permanen bagi mahasiswa yang datang dari tempat jauh.Seiring dengan perkembangan peradaban Islam, pendidikan yang memang telah menjadi perhatian utama sejak awal mengalami kemajuan pesat. Perhatian para bangsawan dan dermawan terhadap bidang ini memungkinkan terdapatnya jaringan kegiatan ilmiah yang meluas dengan dukungan dana yang terjamin. ${ }^{2}$

Lembaga pendidikan Islam tidak bisa dilepaskan dari pandangan atau konsep Islam itu sendiri mengenai pendidikan. Pendidikan Islam merupakan wujud dari pengaruh berbagai kebudayaan atau peradaban yang pernah ada dalam sejarah. Namun demikian para ahli pendidikan Islam biasanya berpandangan bahwa pendidikan Islam memiliki karakter dan tujuannya sendiri yang khas, karena ia didasarkan kepada tujuan mencapai keridaan Allah swt.di dunia dan akhirat. ${ }^{3}$

1Muhammad `Abdul-Mun im Khafaji, Al-Azhar fi Alfi 'Am (Bairut: `Alamul-Kutub, 1407/1987), cet. ke-2, 3 jilid, jilid 1, hlm. 7.

2Hasan Asari. Menyikap Zaman Keemasan Islam (Bandung: Citapustaka Media, 2007), hlm. 72.

3Tajab, et.al., Dasar-Dasar Kependidikan dalam Islam: Suatu Pengantar IImu Pendidikan Islam, dikutip dari Maksum, Madrasah: Sejarah dan Perkembangannya (Jakarta: Logos, 1999), hlm. 24-25. 


\section{Al-Azhar Hingga Abad Ke-19: Review Singkat}

1. Mesir Sebelum Al-Azhar (Kekhalifahan 'Umar ibn Khattab: 13-23/634644)

Peristiwa penaklukkan Mesir terjadi pada tahun $18 \mathrm{H}$, kemudian membangun masjid tahun $21 \mathrm{H}$, yang sekarang dikenal dengan masjid 'Amr ibn al-'As. ${ }^{4}$

2. Mesir Masa Daulah Fatimiyyah ${ }^{5}$

a. Masa Awal

Abu 'Abdillah asy-Syi'i adalah orang pertama yang menyebarkan pemahaman Syi ah kepada masyarakat Barbar Afrika Utara. ${ }^{6}$

\section{b. Berdirinya Daulah Fatimiyyah}

Al-Mu`iz Lidinillah Abu Tamim Ma`d (341/953 - 365/975), pada masa Al-Mu'iz inilah Mesir dapat dikuasai penuh. Panglima perang dalam penaklukannya adalah Jauhar As-Siqilli Ar-Rumi.

4Tempat didirikannya masjid ini (daerah Fustat\}), kemudian menjadi ibukota Mesir dan pusat ilmu. Menetap di sini para sahabat, tabi' in, atba 'ut-tabi' in, dan melahirkan para muttahid seperti al-Lais ibn Sa'd (w. 175 H.), asy-Syafì (w. 204 H.), al-Buwaiti al-Mis\}ri (w. 231 H.). Baca:

1. Muhammad `Abdul-Mun`im Khafaji (w. 1427 H.). Al-Azhar fi Alfi 'Am (Bairut: 'Alamul-Kutub, 1407/1987), cet. ke-2, 3 jilid, jilid 1, hlm. 13-18.

2. 'Abdur-Rahman ibn Abi Bakr, Jalaluddin As-Suyuti (w. 911 H.). HusnulMuhadirah fi Tarikh Misr wal-Qahirah (Mesir: Dar Ihya' al-Kutub al-'Arabiyyah, 1387/1967), cet 1, 2 jilid, jilid 1, hlm. 72.

5Khafaji, hlm. 19.

${ }_{6}^{6}$ Peristiwa ini terjadi tahun 280/893-296/908, dan berhasil mengalahkan khalifah Aglabi (Daulah Abbasiyah). Sejak saat itu kekhalifahan digantikan oleh 'Ubaidullah ibn Muhammad, berasal dari keturunan Ja'far as-Sadiq. Baca: Aiman Fuad Sayyid. Daulah Fatimiyyah fi Misr Tafsir Jadid (Mesir: Darul-Misriyah, 2007), hlm. 30. 


\section{c. Mendirikan Al-Azhar}

Jami` Al-Azhar mulai dibangun pada hari Sabtu bulan JumadilAwwal tahun 359/970, selesai pada tanggal 07 Ramadan tahun 361/22 Juni 972. Materi pembelajaran yang diberikan pada Jami Al-Azhar saat itu adalah fiqh mazhab Fatimi, filsafat, dan tauhid diajarkan oleh 30 orang pendidik.Pendidik yang berjasa pada masa awal adalah Ya`qub ibn Kilis (369). Pada tahun 378/988, beliau mengusulkan untuk mengajarkan secara umum di hari Jum`at materi-materi kesyi ahan, waktunya setelah salat Jum`at hingga waktu Asar.

\section{a. Al-Azhar Masa Daulah Fatimiyyah}

Al-Azhar memulai kegiatan pembelajaran dengan sistem halaqah ilmiah pada tahun 365/976, kemudian berkembang menjadi universitas Islam besar mulai tahun 378/988. Pada tahun 395-masa Al-Hakim dengan mendirikan Darul-Hikmah atau Darul-'Ilm- pembelajaran untuk materi-materi ilmu aqliyah mulai digalakkan, seperti matematika, fisika, kedokteran, falak, dan geografi. ${ }^{7}$

\section{b. Al-Azhar Masa Daulah Ayyubiyyah}

Salahud-Din Yusuf ibn Ayyub adalah pendiri Daulah Ayyubiyyah di mesir tahun 567.8 Di antara jasa beliau adalah menghapuskan paham syi'ah, dengan menutup kegiatan pembelajaran di Al-Azhar

7Mahmud Yunus. Sejarah Pendidikan Islam (Jakarta: PT Hidakarya Agung, 1992), hlm. 175.

8Pengganti setelahnya adalah anaknya bernama 'Imadud-Din 'Usman (w. 595). Setelah itu kekhalifahan dipimpin oleh paman beliau bernama Abu Bakr ibn Ayyub (w. 616), pengganti setelahnya adalah anaknya bernama Muhammad (616-635), Abu Bakr dan Ayyub (637) yang pada masa ini terjadi perang salib. 
selama 1 abad lamanya, dan mendirikan banyak madrasah ${ }^{9}$ untuk penyebaran paham sunni. ${ }^{10}$

\section{c. Al-Azhar Masa Daulah Mamalik (657-923 H.)}

Daulah Mamalik ${ }^{11}$ terdiri dari dua periode, yaitu 1) periode Mamalik Bahriyyah (berakhir 784 H.), 2) periode Mamalik Syara Kisah Bajiyyah (784-923/1382-1517). Pada periode pertama, dibangun Madrasah termegah saat itu yang sekarang dikenal dengan Jami asSultan. Kemudian pada periode kedua dibangun pula Madrasah yang megah dinamai dengan Jami Barquq, dan Jami al-Mu'ayyid. ${ }^{12}$ Kurikulum pada dua periode ini terdiri atas kajian berbagai disiplin ilmu di antaranya sastra dan hukum. Lembaga wakaf juga terorganisir dengan baik sehingga ada madrasah khusus mendidik anak-anak yatim secara gratis.

\section{d. Al-Azhar Masa Daulah `Usmaniyyah}

Daulah 'Usmaniyyah menguasai Mesir pada tahun 923- $1220 \mathrm{H}$. berakhir pada masa pemerintahan Muhammad `Ali. Pada masa Daulah 'Usmaniyyah ini seluruh ilmuan dan buku-bukunya dibawa ke Konstantinopel, dan kini sebagian besar buku-buku tersebut masih ada di perpustakaan Istanbul, di antaranya buku-buku abad ke- 9 Hijrah yaitu al-Maqrizi, as-Suyuti, as-Sakhawi, dan Ibn lyas. Al-Azhar ketika itu bagaikan tempat yang tak berpenghuni, sunyi dari kegiatan ilmiahnya bahkan hampir seluruh kegiatan pembelajarannya disibukkan dengan pembahasan kosakata-kosakata tanpa ada ulasan tertentu, taqlid dan

9Dibangun berdekatan dengan masjid 'Amru madrasah untuk mazhab Syafi i, madrasah mazhab Maliki, Hanafi, dan 25 madrasah di Kairo dan Fustat serta madrasah untuk 4 mazhab.

10Taqiyuddin Al-Maqrizi (w. 845). al-Mawa 'iz wal-/'tibar bi Zikril-Khattat wal-Asar (Beirut: Darul-Kutub al-'Ilmiyyah, 1418), cet 1, 4 juz, juz 4, hlm. 193.

${ }^{11}$ Daulah ini menguasai Mesir tahun $658 \mathrm{H}$ disebut Mamalik karena daulah terdiri atas banyak kesultanan. Pada periode pertama terdiri dari 24 sultan sedangkan periode kedua terdiri atas 23 sultan.

${ }^{12}$ Pada awal tahun $800 \mathrm{H}$. jumlah talib al-Azhar berjumlah 570 orang, dan tahun $818 \mathrm{H}$. bertambah menjadi 750 berasal dari berbagai penjuru dunia. 
pengharaman pengkajian ilmu-ilmu aqliyah. Keadaan seperti ini terus terjadi hingga akhir abad ke-12 Hijrah, masa penguasa Mesir Ahmad Pasya tahun $1161 \mathrm{H} / 1748 \mathrm{M}$, saat itu 'Abdullah asy-Syibrawi yang menduduki jabatan Syaikhul-Azhar. ${ }^{13}$

\section{e. Al-Azhar Setelah Masa Daulah 'Usmaniyyah}

Pada bulan Jumadil-'Ula tahun 1213/ Juli 1798 terjadi peperangan antara Mesir dan Perancis.Demikian pula pada 23 Syawwal 1214/ 20 Maret 1800.14

\section{Perkembangan Sistem Pendidikan Al-Azhar (1900- Sekarang) sebagai Sebuah Lembaga Pendidikan Tertua di Dunia}

\section{Tujuan Pendidikan di Al-Azhar}

Misi al-azhar di antaranya adalah mengembangkan nilai keislaman yang universal, teloransi, moderat, sehingga menjadi rahmatal-lil 'alamin dalam menyebarkan agama dan budaya Islam. Untuk tujuan ini, para Ilmuan Islam mengeluarkan fatwa untuk menjawab berbagai permasalahan yang ditanyakan kepada mereka dari seluruh dunia. Al-Azhar juga melatih para pendakwah yang ditunjuk oleh pemerintah Mesir.

Adapun tujuan Universitas al-Azhar secara rinci adalah: (1) mengemukakan kebenaran dan pengaruh turas Islam terhadap kemajuan umat manusia dan jaminannya terhadap kebahagiaannya di dunia dan akhirat; (2) memberikan perhatian penuh terhadap ke-bangkitan turas ilmu, pemikiran, dan keruhanian; (3) menyuplai dunia Islam dengan ulama-

\footnotetext{
13Kebijakan adanya jabatan Syaikhul-Azhar dimulai pada abad ke-10 Hijrah. Syaikhul Azhar pertama adalah `Abdullah al-Kharasyi (w. $1101 \mathrm{H}$ )

14Peperangan ini menginspirasi al-Azhar untuk memperbaharui sistem pendidikannya. Sebelum kedatangan ekspedisi ini orang Mesir tidak pernah kenal pada percetakan, majalah atau surat kabar, alat-alat ilmiah, seperti teleskop, mikroskop, alatalat untuk percobaan kimiawi. Sehingga Abdur-Rahman al-Jibrati, seorang ulama dari alAzhar dan penulis sejarah, pernah mengunjungi lembaga (suatu lembaga ilmiah bernama Institut d'Egypte) di tahun 1799. Kesimpulan tentang kunjungan itu ia tulis: "Saya lihat di sana benda-benda dan percobaan-percobaan ganjil yang menghasilkan hal-hal besar untuk dapat ditangkap oleh akal seperti yang ada pada diri kita."
} 
ulama aktif yang beriman, percaya terhadap diri sendiri, mempunyai keteguhan mental dan ilmu yang mendalam tentang akidah, syariah, dan bahasa al-Quran; (4) mencetak ilmuwan agama yang aktif dalam semua bentuk kegiatan, karya, kepemimpinan dan menjadi contoh yang baik, serta mencetak ilmuwan dari berbagai ilmu pengetahuan yang sanggup aktif dalam dakwah Islam yang dipimpin dengan hikmat kebijaksanaan dan pelajaran yang baik di luar dan di dalam negeri; (5) meningkatkan hubungan kebudayaan dan ilmiah dengan universitas dan lembaga ilmiah Islam di luar negeri. ${ }^{15}$

\section{Kurikulum ${ }^{16}$}

Awal abad 20 (1928) sistematisasi Universitas al-Azhar dimulai dengan membuka tiga fakultas: bahasa arab, syariah, dan fakultas usuludin, namun setelah keluar undang-undang nomor 103 tahun 1961 disebut undang undang pengembangan al-Azhar, mulai membuka fakultas lainnya, saat ini ada 62 fakultas yang tersebar dari Utara sampai Selatan ditambah 6 cabang lagi sehingga menjadi 68 fakultas. ${ }^{17}$

${ }^{15}$ Abuddin Nata. Sejarah Pendidikan Islam (Jakarta: PT Raja Grafindo Persada, 2004), hlm. 93-94.

16Khafaji, hlm. 33, 35, 74, 108-112, 126, 179.

${ }_{17}^{17} \mathrm{Al}-\mathrm{Azh}$ ar membagi fakultas menjadi dua, yaitu ilmy dan adaby. Hal ini dimaksudkan untuk mengikuti perkembangan zaman. Selain itu kefakultasan dibagi menjadi dua: putra dan putri. Kefakultasan untuk putra dalam kategori IImy. Fakultas Kedokteran, Perniagaan, Pertanian, Bahasa dan Terjemah, Ekonomi, Pendidikan, Teknik, Farmasi, Kedokteran gigi, dan Fakultas Eksakta (sains). Adapun dari segi Adaby adalah pertama: Fakultas Ushuludin yang mencakup Jurusan Tafsir, Hadis, dan Filsafat. Semuanya ditempuh dalam waktu 4 tahun.Kedua, Fakultas Syariah wal Qanun. Ketiga, Fakultas Bahasa, yang mencakup Jurusan Lugah Arabiyah, Jurusan Jurnalistik dan publikasi. Semuanya ditempuh dalam waktu 4 tahun. Keempat, Fakultas Studi Islam (jenjang pendidikan selama 4 tahun). Kelima, Fakultas Dakwah Islamiyah (jenjang pendidikan 4 tahun).

Kefakultasan Adaby dan IImy untuk putri tidak kalah banyaknya. Dalam kategori Adaby adalahFakultas Studi Islam dan Bahasa Arab, Syariah wal Qanun, Usuludin (Tafsir, 
Pendidikan di Mesir melaksanakan dua sistem yaitu Sistem Pendidikan Kebangsaan dan Sistem Pendidikan Al-Azhar.

\section{a. Sistem Pendidikan Kebangsaan}

Di bawah sistem ini, pendidikan rendah, menengah dan tinggi ditanganioleh Kementerian Pendidikan. Tempo pendidikan di bawah sistem ini adalah:

1) Pendidikan Rendah (ibtidal): 6 tahun

2) Pendidikan Menengah Rendah (i"dadi): 3 tahun

3) Pendidikan Menengah Atas (sanawi): 3 tahun

4) Pendidikan Universitas (jamiah): 4-6 tahun

Terdapat 11 universitas di bawah Sistem Pendidikan Kebangsaan yaitu: Universitas Qahirah, Universitas Ain Syams, Universitas Al-Mania, Universitas Mansurah, Universitas Hilwan, Universitas Terusan Suez, Universitas Iskandariah, Universitas Asyut, Universitas Tanta, Universitas Zaqaziq, Universitas Al-Manufia.

\section{b. Sistem Pendidikan Al-Azhar}

Semua pusat pendidikan Al-Azhar dari pendidikan rendah hingga pendidikan tinggi di bawah wewenang Majlis Tertinggi Al-Azhar yang diorganisir oleh Syekh Al-Azhar. Tempo pendidikan di bawah sistem ini adalah:

1) Pendidikan Rendah (ibtidal): 6 tahun

2) Pendidikan Menengah Rendah ( $i$ dad $): 3$ tahun

3) Pendidikan Menenengah Atas (sanawi): 4 tahun

Ulumul-Quran, Hadis dan Ulumul-Hadis, Aqidah dan Filsafat. Untuk masa studi sama dengan putra. Untuk kefakultasan dalam kategori Ilmy untuk putri yaitu Fakultas Farmasi, Ekonomi, Kedokteran, Eksakta, dan Fakultas Studi Kemanusiaan, yang memiliki beberapa bidang, yaitu:

1. Bidang Humaniora, dibagi menjadi Jurusan Sosiologi, IImu Jiwa, Sejarah dan Geografi

2. Bidang Bahasa Eropa dan Terjemah Langsung, yang mencakup Jurusan Bahasa Inggris dan Terjemah, Bahasa Perancis dan Terjemah, Bidang Bahasa Timur (Bahasa Persia dan Ibrani), Bidang Manuskrip, Perpustakaan dan Informasi. Adapun jenjang pendidikan ditempuh dalam 4 tahun. 
4) Pendidikan Universiti (jami ah): 4-6 tahun

Sistem pendidikan Mesir, baik Negeri maupun Al-Azhar, dan pendidikan swasta lainnya, mewajibkan pelajar Muslim untuk menghafal Alquran. Selain itu, pengajian di Masjid-masjid bagi jamaah, khususnya anak-anak sekolah juga berperan penting untuk mendorong warga menghafal Alquran, kata Menteri Zakzouk, yang juga mantan dekan fakultas teologi Universitas Al-Azhar tersebut.

Sistem pendidikan di Mesir, sejak taman kanak-kanak sudah diwajibkan menghafal Alquran. Di Universitas Al-Azhar, misalnya, bagi mahasiswa Mesir program S-1 diwajibkan menghafal 15 juz (setengah) Alquran, program S-2 diwajibkan menghafal seluruh Alquran. Adapun program S-3, tinggal diuji hafalan sebelumnya.

Kewajiban hafal Alquran ini tidak berlaku bagi mahasiswa asing (non-Arab), dimana program S-1 diringankan, yaitu hanya diwajibkan hafal 8 juz Alquran, dan program S-2 sebanyak 15 juz Alquran, sementara program S-3 baru diwajibkan hafal seluruh Alquran. Sementara itu, Pemerintah Mesir dalam setiap tahun mengalokasikan dana khusus sebesar 25 juta dolar AS (1,2 miliar pound Mesir) untuk penghargaan bagi penghafal Alquran.

Kemudian keberadaan Perpustakaan al-Azhar dianggap nomor dua terpenting di Mesir setelah Perpustakaan dan Arsip Nasional Mesir. AlAzhar yang bermitra dengan ITEP, suatu perusahaan teknologi informasi Dubai, pada bulan Mei 2005 meluncurkan Proyek YM Sheikh Mohammed bin Rashid Al-Maktoum untuk melestarikan dan mempublikasikan Naskah al-Azhar secara online (Proyek Al-Azhar Online); dengan membawa misi untuk memberikan akses online kepada masyarakat atas seluruh koleksi manuskrip langka yang dimiliki perpustakaan Al-Azhar.

\section{Organisasi}

\section{a. Otoritas}

Sistem pendidikan Mesir adalah tanggung jawab Kementrian Negara. Kementrian Pendidikan bertanggung jawab mulai dari pendidikan prasekolah sampai ke pendidikan tinggi dalam aspek 
perencanaan, kebijakan, kontrol kualitas, koordinasi dan pengembangannya. Pejabat-pejabat pendidikan di tingkat provinsi bertanggung jawab atas implementasinya. Mereka yang memiliki lokasi, membangun, dan melengkapi serta mengawasinya agar berjalan dengan baik. Mereka berusaha mendorong sumbangan dana partisipasi masyarakat dan ikut bertanggung jawab atas segala sesuatu untuk menjamin terselenggaranya operasional dengan efisien.

Menteri melaksanakan sidang dalam waktu-waktu tertentu dengan Dewan-Dewan yang berada di bawah Kesekretariatan dan sejumlah Dewan-Dewan lain. Menteri juga memimpin sidang Dewan Universitas yang bertanggung jawab atas prencanaan dan pembuatan kebijakan. Mesir juga dibagi dalam 140 distrik pendidikan dengan jaringan supervisor dan administrator. ${ }^{18}$

\section{b. Dewan Tertinggi Al-Azhar}

Undang Undang nomor 193 menetapkan adanya Badan Judikatif yang mempunyai hak meninjau aturan dan undang-undang yang diberlakukan untuk perjalanan pendidikan dan manajemen di AlAzhar dan lembaga-lembaga pendidikan agama. Badan ini disebut Majelis Tertinggi Al-Azhar, yang terdiri dari:

1) Syekh Jami` Al-Azhar

2) Deputi (Wakil) Jami Al-Azhar dan lembaga-lembaga pendidikan Islam. la berhak memegang kepemimpinan majelis apabila Syekh Al-Azhar berhalangan

3) Mufti Diyar Misriyah

4) Para Syekh pada setiap Fakultas

5) Deputi Departemen A/-Haqqaniyah

6) Deputi Departemen Wakaf

7) Deputi Departemen Hubungan Sosial

8) Deputi Departemen Keuangan

18Agustiar Syah Nur. Perbandingan Sistem Pendidikan 15 Negara (Bandung: Lubuk Agung, 2001), hlm. 15. 
9) Dua pejabat anggota Lembaga Tokoh Agama yang ditetapkan dengan mandat Presiden selama dua tahun

10)Dua pejabat yang eksistensinya berguna bagi kepentingan pendidikan di Al-Azhar dan lembaga-lembaga pendidikan Islam dan diputuskan dengan mandat presiden selama dua tahun.

\section{c. Struktur Lembaga Al-Azhar}

Berdasarkan undang-undang revolusi yang dikeluarkan tahun 1961, institusi Al-Azhar terdiri dari elemen-elemen sebagai berikut:

1) Syekh Al-Azhar (Al-Imam Al-Akbar/Grand Syekh), pimpinan tertinggi institusi Al-Azhar, diangkat melalui ketetapan Presiden dari salah satu anggota Majma` Al-Buhus Al-Islamiyah, atau orang yang memenuhi persyaratan untuk menjadi anggotanya

2) Wakil Syekh Al-Azhar, yang harus memenuhi syarat seperti yang disyaratkan bagi Syekh Al-Azhar

3) Diangkat juga kementrian Al Azhar

Disamping itu, ditetapkan lima badan atau lembaga yang menginduk kepada Al Azhar, yaitu:

a) Al-Majlis A la lil-Azhar (Majelis Tinggi Al-Azhar)

b) Majma' Al-Buhus Al-Islamiyah (Lembaga Riset Islam)

Lembaga ini memiliki tiga divisi: Divisi Al-Buhus Al-Islamiyah, Divisi $A d-D a$ 'wah wal-Irsyad, dan Divisi Riset dan Penerbitan yang mengelola majalah Al-Azhar

c) Kantor kebudayaan dan Al-Buhus Al-Islamiyah (kemudian digabung ke dalam Majma' Al-Buhus Al-Islamiyah)

d) Universitas Al-Azhar

e) Al-Ma`ahid Al-Azhariyah.

Syekh dan Rektor Al-Azhar, keduanya mempunyai posisi penting, tetapi jangkauan perannya berbeda. Syekh Al-Azhar memimpin keseluruhan lembaga Al-Azhar sedangkan Rektor AlAzhar hanya menangani Universitas.

\section{d. Para Syekh Al-Azhar}

Pada akhir abad ke XI H/XVII M ditetapkanlah kedudukan Syekh Al-Azhar sebagai pimpinan tertinggi. Sejak abad ini sistem Syekh atau 
Imam Al-Akbar merupakan ciri khusus yang digunakan dalam lembaga tersebut, bahkan dapat dikatakan suatu sistem yang mampu memelihara eksistensi Al-Azhar hingga ratusan tahun. Ada sepuluh Syekh yang berada pada masa Daulah ini.

Kemudian pada akhir tahun $1220 \mathrm{H} / 1805 \mathrm{M}$. Mesir berada di tangan Muhammad Ali. Al Azhar tetap baku menggunakan sistem Masya'ikh-nya. Selanjutnya nama-nama Imam yang menduduki kursi Masya'ikh sebanyak dua puluh sembilan.

Pada dua kepemimpinan belakangan ini Mesir tengah mengalami kegoncangan politik besar-besaran, sebagai periode baru menuju Mesir Modern, ditandai dengan terjadinya revolusi Juli 1952 M. yaitu penggulingan Gamal Abdul Naser terhadap raja Faruq Dinasty Kheidio, sekaligus peralihan sistem Kerajaan ke sistem Republik dan pengembalian ibukota dari Iskandariyah ke Kairo. Adapun sistem Masya'ikh Al-Azhar terus berlangsung sebanyak delapan, termasuk kini Syekh Ahmad Tayyib yang menjabatnya.

Berkaitan dengan kisruh pemerintahan di Mesir, betapa al-Azhar memainkan peranan yang strategis.Berdasarkan informasi dari Republika pada tanggal 06 Juli 2014, sejak militer Mesir memberhentikan Muhammad Mursi dari jabatannya sebagai presiden dan diangkatnya ketua Mahkamah Konstitusi, Adli Mansur, sebagai presiden sementara, para pendukung Mursi Ikhwanul Muslimin dan sayap politiknya, Partai Keadilan dan Pembangunan, serta sejumlah partai dan ormas Islam-menyatakan, pemberhentian Mursi sebagai kudeta militer. Sebab, Mursi merupakan presiden pilihan rakyat Mesir secara demokratis setahun lalu. Selama menjabat presiden, ia tak pernah melanggar konstitusi atau pelanggaran berat lainnya yang dapat dijadikan alasan melengserkannya.

Sebaliknya, para penentang Mursi seperti kelompok liberal, sekuler, sosialis, dan militer mengatakan, pencopotan Mursi sebagai pelurusan Revolusi 25 Januari 2011 yang menjatuhkan rezim presiden Husni Mubarak. Minimal ada dua tuduhan yang mereka kemukakan sebagai alasan penggulingan. Pertama, Mursi dituduh sedang 
menjadikan Mesir sebagai negara Ikhwanul Muslimin atau lebih tepatnya, ia sedang memperjuangkan nilai-nilai Islam pada pemerintahannya. Kedua, pemerintahan Mursi dianggap tidak profesional mengurus negara, karena ekonomi Mesir terus memburuk selama setahun terakhir ini. Tuduhan-tuduhan yang tentu saja ditolak oleh Mursi dan para pendukungnya.

Yang patut disayangkan, ternyata kelompok-kelompok Islam di Mesir tidak cukup solid mendukung pemerintahan Mursi. Dalam setiap zaman selalu saja muncul kelompok petualang politik. Kelompok yang melihat "ke mana angin bertiup kencang ke sana mereka mengarah". Kelompok Salafi di Mesir misalnya, melalui sayap politiknya, Partai anNoor, semula mendukung Mursi. Namun, lantaran jabatan yang diberikan dianggap tidak sesuai, mereka pun membelot ke pihak militer dan oposisi. Demikian pula sikap Grand Syekh Al-Azhar, Syekh Ahmad Tayyib.

Meskipun tidak terkait dengan jabatan secara langsung, namun Ahmad Tayyib dilihat dari perjalanan hidupnya-pada masa rezim Mubarak, ia merupakan pendukung setianya. Bahkan, ketika muncul aksi-aksi demonstrasi melawan Mubarak, sikapnya tidak jelas. Baru setelah kelihatan Mubarak mau jatuh, ia pun berbelot ke revolusi rakyat yang akhirnya menjatuhkan Mubarak. Malah ia sempat mengeluarkan fatwa, meskipun terlambat, bahwa demonstrasi dan bahkan melawan penguasa tiran dibolehkan. Karena itu, ia pun mendukung oposisi Suriah menjatuhkan Presiden Basyar al-Assad.

Pada pemerintahan Mursi, Al-Azhar bahu-membahu dengan kelompok Islam lainnya, terutama Al-lkhwan Muslimin, untuk mengamendemen konstitusi negara. Kostitusi baru-yang kemudian disetujui rakyat melalui referendum ini meletakkan Al-Azhar pada posisi strategis. Yakni, segala undang-undang dan peraturan yang terkait dengan agama harus mendapat persetujuan dari Al-Azhar.Namun, ketika aksi-aksi demo menentang Mursi semakin membesar dan akhirnya didukung militer untuk menjatuhkan Mursi, Syekh Al-Azhar Ahmad Tayyib tiba-tiba ikut menentang kekuasaan Mursi yang Islami. 
Bahkan, ia ikut mendampingi Panglima Angkatan Bersenjata Jenderal Abdul Fattah as-Sisi ketika membacakan pengumuman pemberhentian Mursi dari jabatannya sebagai presiden. Ahmad Tayyib duduk berdampingan dengan Uskup Koptik Mesir, Uskup Tawadrus II, dan sejumlah tokoh sekuler-liberal yang menentang kekuasaan Mursi. Alasan yang dikemukakan sebagaimana dikutip Aljazirah.net adalah untuk menghindarkan pertumpahan darah sesama rakyat Mesir. Bahkan, Syekh Al-Azhar menyebut demonstrasi yang mendukung dan menentang Presiden Mursi tidak ada kaitannya dengan agama, tetapi demi kekuasaan. Menurutnya, alasan mendukung kudeta militer sebagai menghindarkan terjadinya perang saudara.

Sikap dan pertanyataan Syekh Al-Azhar itu segera direspons oleh Ketua Persatuan Ulama Dunia, Syekh Yusuf Qaradhawi: "Syekh Tayyib, ketua lembaga ulama-ulama besar Mesir (rais kibarul ulama) telah berbicara atas nama kami. Dia telah bersalah ketika mendukung kudeta militer untuk memberhentikan presiden yang sah dan yang terpilih secara demokratis. Dia telah berseberangan dengan kesepakatan ulama Islam dunia. Karena itu, pendapatnya adalah pribadi dan bukan atas nama para ulama. Pendapatnya yang mendukung kudeta militer untuk menjatuhkan presiden yang sah dan terpilih secara demokratis tidak bersandarkan pada Alquran maupun Sunnah sama sekali".

Mendapat serangan dari Syekh Qaradhawi, Syekh Al-Azhar tampaknya tidak mau berhadapan dengan koleganya itu. la hanya mengatakan akan terus beri'tikaf (berdiam diri) di rumahnya sembari mendokan yang terbaik untuk bangsa Mesir. Namun, melalui keterangan pers, Al-Azhar membantah semua pernyataan Syekh Qaradhawi. Menurutnya, pendapat Qaradhawi merupakan fitnah dan ia (Qaradhawi) tidak melihat kenyataan besarnya demo oposisi. Bila hal itu dibiarkan justru akan menimbulkan pertumpahan darah yang tidak perlu," bunyi keterangan pers Al-Azhar sebagaimana dikutip Al-Ahram.

Qaradhawi dan Ahmad Tayyib sama-sama lulusan Al-Azhar. Qaradhawi sering disebut sebagai mewakili kelompok Islam politik. 
Sedangkan, Syekh Al-Azhar mewakili kelompok Islam kultural.Qaradhawi yang kini bermukim di Qatar selalu terlibat aktif-baik fisik maupun melalui fatwa-fatwanya-dalam gerakan dan revolusi rakyat melawan penguasa zalim seperti rezim Husni Mubarak dan kini rezim Basyar al-Assad.Qaradhawi juga merupakan anggota Lembaga Ulama Besar Mesir yang diketuai Syekh Tayyib. Sebaliknya, Syekh Tayyib merupakan anggota Persatuan Ulama Dunia yang dipimpin Syekh Qaradhawi.

Baik Syekh Qaradhawi maupun Syekh Al-Azhar masing-masing mempunyai pengikut di berbagai belahan dunia Islam, termasuk di Indonesia. Karena itu, perkembangan di Mesir, termasuk silang pendapat dan perbedaan fatwa antara Syekh Qaradhawi dan Syekh AlAzhar terhadap penggulingan pemerintahan Presiden Mursi yang Islami akan sangat menarik diikuti. Perbedaan pandangan Qaradhawi dengan Ahmad Tayyib sedikit banyak berpengaruh pada perkembangan fikih politik di dunia Islam.

Kemudian berdasarkan pemberitaan Islam Pos pada 05 Mei 2014, Al-Azhar telah memecat 76 mahasiswa dari fakultas yang berbeda atas tuduhan keterlibatan mereka dalam kerusuhan, kantor berita Mesir MENA melaporkan. Bentrokan terus-menerus antara pasukan keamanan dan mahasiswa di beberapa kampus telah memuncak dengan adanya beberapa kematian di antara barisan mereka. Puluhan mahasiswa Al-Azhar telah adili, dengan puluhan dihukum karena keterlibatan mereka dalam bentrokan dengan polisi.

Rektor Universitas Al-Azhar Osama El-Abd mengatakan bahwa penyelidikan membuktikan para mahasiswa yang dipecat ikut ambil bagian dalam kegiatan yang melanggar aturan al-Azhar dan 36 dari mereka adalah mahasiswi dari cabang universitas Al-Azhar di kota Delta Nil Zagazig, menurut laporan MENA.

Presiden interim Mesir Adly Mansour mengubah hukum pada bulan Februari lalu sehingga memungkinkan kepala Universitas mengusir mahasiswa yang melakukan aksi protes. 
4. Jaringan

Universitas Al-Azhar tidak hanya berpusat di Kairo saja. Tetapi terdapat banyak cabang di luar Kairo, di antaranya:

\section{a. Untuk Putra}

1) Fakultas Usuludin dan Dakwah, juga Fakultas Bahasa Arab di Zaqaziq

2) Fakultas Usuludin dan Dakwah, juga Fakultas Syari’ah dan Qanun di Tanta

3) Fakultas Usuludin dan Dakwah, juga Fakultas Bahasa Arab di Mansurah

4) Fakultas Usuludin dan Dakwah, juga Fakultas Bahasa Arab di Syibin el-Koum

5) Fakultas Syariah dan Qanun, juga Bahasa Arab di Damanhur

6) Fakultas Studi Islam dan Bahasa Arab di Dimyat

7) Fakultas Alquranul-Karim dan IImu Qira'at di Tanta

8) Faklutas Syariah dan Qanun di Daqahliyah

9) Fakultas Usuluddin dan Dakwah, Fakultas Syariah dan Qanun, Fakultas 'Ulum (Sains), Fakultas Kedokteran, Fakultas Farmasi, Fakultas Bahasa Arab di Asyut

10)Fakultas Studi Islam dan Bahasa Arab di Qena

11)Fakultas Bahasa Arab di Garga

12)Fakultas Studi Islam dan Bahasa Arab di Aswan

\section{b. Untuk Putri}

1) Fakultas Studi Islam dan Bahasa Arab di Iskandariyah

2) Fakultas Studi Islam dan Bahasa Arab di Mansurah

3) Fakultas Ekonomi Rumah Tangga di Tanta

4) Kulliyantul-Banat di Asyut

5) Fakultas Studi Islam dan Bahasa Arab di Suhaj

\section{Pengaruh}

Seperti yang terjadi di banyak negara lain, di Indonesia pun perkembangan ajaran Islam tidak dapat dipisahkan dari keberadaan alAzhar. Pengaruhnya tak dapat dinafikan dalam pertumbuhan modernisasi 
Islam di Tanah Air. Al-Azhar menjadi saksi hubungan antara IndonesiaMesir. Menurut Soekarno, Indonesia mengenal Mesir itu justru karena ada al-Azhar. ${ }^{19}$ Pada tahun 1960, Presiden Sukarno menerima gelar Doctor Honoris Causa dari Al-Azhar. Selain Bung Karno, penganugerahan Doktor kehormatan dari al-Azhar sebelumnya diberikan kepada Haji Abdul Malik Karim Amrullah (HAMKA) pada tanggal 21 Januari 1958.

Sekarang ini kurang lebih 2.516 mahasiswa Indonesia sedang belajar di universitas tersebut, ${ }^{20}$ mengisahkan dengan baik sejarah, dan peranannya dalam mengembangkan pola pendidikan dan pandangan keislaman moderat dalam konteks global.

\section{a. Sistem Wakaf}

Wakaf merupakan satu tradisi sosial yang diturunkan oleh Rasulullah saw. dimana tradisi tersebut dipegang kuat oleh sahabatsahabat dan para pengikutnya. Sistem wakaf telah memberikan manfaat dan melahirkan para ilmuan serta berbagai institusi dalam peradaban Islam.

Di antara pusat pengkajian Islam ternama hasil dari amalan wakaf termasuk Universitas Al-Azhar. Hingga saat ini, hasil wakaf di Mesir dalam batas-batas tertentu masih didistribusikan untuk keadilan sosial, meski belum maksimal. Hasil wakaf di Mesir diberikan untuk bidang: 1) Dakwah Islam; antara lain untuk para khatib, takmir mesjid, para penghafal Alquran, dan penerjemahan Alquran. 2) Bidang pendidikan dan pelatihan; antara lain untuk lembaga pendidikan yatim piatu dan beasiswa bagi sebagian mahasiwa al-Azhar, baik dari dalam maupun luar negeri. Jumlahnya sebanyak 700 orang kali 4 angkatan. Setiap mahasiswa memperoleh 160 Found Mesir (sekitar Rp. 240.000). 3) Bidang penyebaran kebudayaan Islam seperti penerbitan buletin Islam, pencetakan buku-buku dan ensiklopedi Islam, penelitian

19http://soekarnocare.org/2014/03/11/soekarno_dikenang/ diakses 12 Juni 2014, pukul 00.05 WIB.

20http://www.atdikcairo.org/data-pendidikan/cek-data-lapor-pendidikan

diakses 15 Maret 2014, pukul 11.00 WIB. 
filologis naskah kuno Islam, dan penyelenggaraan pameran kebudayaan Islam. 4) Bidang sosial, seperti bantuan eknomi bagi yang tidak mampu dan bantuan kesehatan. ${ }^{21}$

\section{b. Sistem Riwaq}

Secara kelembagaan, meskipun masih kontroversi, teori tentang asal-usul pesantren dapat dipetakan menjadi dua. Pendapat pertama, pesantren merupakan kesinambungan dari lembaga pendidikan keagamaan pra-Islam, seperti perdikan, sama sekali bukan struktur lembaga baru yang diimpor. Pendapat kedua mengatakan bahwa pesantren diadopsi dari sistem riwaq sebuah sistem pendidikan Islam di Al-Azhar. ${ }^{22}$

Sistem pendidikan pesantren memiliki persamaan baik dengan sistem pendidikan di Timur Tengah maupun dengan lembaga pendidikan Hindu-Budha.Tradisi kedua sistem pendidikan ini berubah sifat khasnya menjadi unsur-unsur kebudayaan campuran (konvergensi) yang muncul dalam pesantren. ${ }^{23}$

\section{Analisis Kritis Terhadap Sistem Al-Azhar}

Al-Azhar adalah produk sekaligus pembangun peradaban.Sebagai lembaga pendidikan yang didirikan oleh Dinasti Fatimiyyah, Al-Azhar merupakan sebuah bukti peradaban yang maju kala itu. Sementara dalam proses perkembangannya, Al-Azhar sebagai perguruan tinggi merupakan bengkel gerakan intelektual yang menjadi saksi sejarah atas konteks yang berlaku di sekitarnya sehingga mempengaruhi perkembangan intelektual di dalamnya, tetapi juga sebagai penghasil pemikiran dan berbagai produk

21Muhammad Abdul-Halim Umar, Tajribah Idarah al-Auqaf fi Jumhuriyyah Misr al'Arabiyyah, (Kairo: Markaz Salih Kamil, tt.), hlm. 31; Abu Bakar Ahmad bin Umar asSyaibani, Kitab Ahkam al-Auqaf, (Kairo: Maktabah as-Saqafah ad-Diniyyah, tt.), hlm. 294295.

22Martin Van Bruinessen, Kitab Kuning: Pesantren dan Tarekat (Bandung: Mizan, 1992), hlm. 35.

23Hanun Asrahah, Pesantren di Jawa Asal-Usul, Perkembangan dan Pelembagaan (Jakarta: Depag RI-INCIS, 2002), cet. 1, hlm. 3. 
turunannya yang mempengaruhi masyarakat dan perkembangan keilmuan Islam. Tidak hanya mempengaruhi perkembangan keilmuan dan pendidikan di dunia Arab, Al-Azhar pun menjadi kiblat pendidikan dunia Islam, termasuk di Indonesia.

Peranan al-Azhar sebagai penjaga turas terkait dengan jatuhnya Baghdad dan Andalusia, yang menimbulkan "kepanikan intelektual", yang berimplikasi pada munculnya penulisan syarah, ikhtisar, hawasyi dan taqarir guna merekonstruksi dan menjaga warisan intelektual Islam. Penjagaan turas ini berperan penting dalam penyediaan rujukan primer dalam keilmuan Islam, akan tetapi jika hal ini berlanjut pada sikap keilmuan yang eksklusif dan bahkan penolakan terhadap khazanah keilmuan yang baru, tentu hal ini justru membahayakan perkembangan keilmuan Islam. Sempitnya khazanah keilmuan hanya menghasilkan kemandekan ilmu pengetahuan yang bisa mengakibatkan kegagapan umat Islam dalam menghadapi kehidupan yang terus berkembang dan akhirnya menjadikan umat Islam hanya sebagai konsumen dari produk keilmuan dan teknologi yang dihasilkan Barat. Implikasi lainnya adalah sistem pendidikan yang cenderung dikotomis, tidak berimbang dan tidak terpadu antara fakultas agama dan "non-agama" pun menciptakan ketimpangan keilmuan yang akhirnya sulit untuk menjawab tantangan dan kebutuhan masyarakat Islam masa kini, bahkan memunculkan kebingungan pada masyarakat dalam menyikapi problem-problem kehidupan. ${ }^{24}$

Berbeda dengan kebanyakan universitas lain yang sudah memberlakukan sistem modern dan canggih, al-Azhar hingga kini masih eksis dengan sistem klasiknya (sistem administrasi yang masih manual menggunakan tulisan tangan). Hal ini pula yang membuat para mahasiswa harus mengantri panjang, bahkan harus menunggu berhari-hari untuk menyelesaikan administrasi kuliah.

Tidak adanya absensi di semua tingkat kuliah layaknya universitasuniversitas lain, kecuali beberapa tingkat saja. Mahasiswa di sini begitu

${ }^{24}$ Kusmana (ed.). Belajar Islam ke Timur Tengah (Departemen Agama Republik Indonesia), hlm. 69. 


\section{Muhammad Idris}

bebas dalam perkuliahan, hal ini memang terlihat rancu dan kurang kondusifnya sistem pembelajaran di al-Azhar. Begitu juga dengan ruang kuliah, al-Azhar masih menggunakan meja dan bangku panjang yang bisa diduduki sekitar lima sampai tujuh orang, yang seharusnya mahasiswa duduk sendiri-sendiri layaknya perkuliahan lain.

\section{Penutup}

Al-Azhar dalam perkembangannya, bukan saja sebagai tempat untuk mendalami ilmu agama atau penampungan bagi orang-orang miskin, bahkan al-Azhar juga merupakan tempat pemersatu umat dalam perjuangan membebaskan Mesir dari penjajahan. Meskipun para penulis sejarah Al-Azhar menyatakan mulai tahun 1872 sebagai tahun di mana pendidikan telah modern, tapi baru pada kepemimpinan Syaikh Hasunah An-Nawawi Al-Hanafi (Syaikhul-Azhar ke 24 dan 29) kira-kira mulai tahun 1903 kurikulum ilmu-ilmu aqliyah dimasukkan ke dalam kurikulum pendidikan al-Azhar.

Keistimewaan al-Azhar, tidak hanya piawai dalam melahirkan ulama-ulama yang berkualitas, akan tetapi ia juga membangun peradaban dunia melalui dua cara, yaitu dengan kepribadian yang dimiliki oleh alAzhar sendiri, dan melalui lulusan-lulusannya yang membawa perubahan terhadap masyarakat dunia. Dalam memainkan peranannya tentu ada kekurangan-kekurangan yang tidak akan dapat dihindari. Namun, karena perubahan merupakan sebuah sunnatullah, al-Azhar terus mengalami peningkatan kemajuan dari zaman ke zaman.

Sungguh, al-Azhar adalah sejarah yang berjalan, selama 1000 tahun lebih ia menjadi saksi atas perubahan-perubahan sistem pemerintahan, pengalihan kekuasaan, saksi akan kelahiran para ulama, ilmuan, dan filosof yang terkenal sampai sekarang, dan diusianya yang sangat tua, ia tetap menjadi idola untuk mendalami ilmu agama. Al-Azhar tidak hanya menjadi sejarah, tetapi menyaksikan dan mengukir sejarah dalam keajaiban dunia pendidikan dan peradaban.Dan keberadaan alAzhar bukti nyata bahwa Islam adalah agama yang peduli terhadap pendidikan, kesehatan, kesenian, serta ilmu pengetahuan umum lainnya. 


\section{Daftar Pustaka}

Hasan Asari. Menyikap Zaman Keemasan Islam, Bandung: Citapustaka Media, 2007.

Hanun Asrahah. Pesantren di Jawa Asal-Usul, Perkembangan dan Pelembagaan, Jakarta: Depag RI-INCIS, 2002.

Bruinessen, Martin Van. Kitab Kuning: Pesantren dan Tarekat Bandung: Mizan, 1992.

Khafaji, Muhammad `Abdul-Mun`im. Al-Azhar fi Alfi 'Am, Beirut: `AlamulKutub, 1407/1987.

Kusmana (ed.). Belajar Islam ke Timur Tengah, Departemen Agama Republik Indonesia.

Al-Maqrizi, Taqiyuddin. Al-Mawa 'iz wal-l'tibar bi Zikril-Khattat wal Asar, Beirut: Darul-Kutub al-'Ilmiyyah, 1418.

Abuddin Nata. Sejarah Pendidikan Islam, Jakarta: PT Raja Grafindo Persada, 2004.

Agustiar Syah Nur. Perbandingan Sistem Pendidikan 15 Negara, Bandung: Lubuk Agung, 2001.

As-Suyuti, `Abdur-Rahman ibn Abi Bakr, Jalaluddin. Husnul-Muhadirah fi Tarikh Misr wal-Qahirah, Mesir: Dar Ihya' al-Kutub al-'Arabiyyah, $1387 / 1967$.

Sayyid, Aiman Fu'ad. Daulah Fatimiyyah fi Misr Tafsir Jadid, Mesir: Darul Misriyah, 2007.

As-Syaibani, Abu Bakar Ahmad bin Umar. Kitab Ahkam al-Auqaf, Kairo: Maktabah as-Saqafah ad-Diniyyah. tt.

Tajab.et. al., Dasar-Dasar Kependidikan dalam Islam: Suatu Pengantar IImu Pendidikan Islam, dikutip dari Maksum. Madrasah: Sejarah dan Perkembangannya, Jakarta: Logos, 1999. 
Muhammad Idris

Umar, Muhammad Abdul-Halim. Tajribah Idarah al-Auqaf fi Jumhuriyyah Misr al-'Arabiyyah, Kairo: Markaz Salih Kamil, tt.

Mahmud Yunus. Sejarah Pendidikan Islam, Jakarta: PT Hidakarya Agung, 1992. 